\title{
MEMBANGUN PENDIDIKAN POLITIK DALAM FATSUN DEMOKRASI PANCASILA DAN DELIBERATIVE
}

\author{
Nadir $^{* 1}$, Win Yuli Wardani ${ }^{2}$ \\ ${ }^{1}$ Prodi Ilmu Hukum, Universitas Madura, Pamekasan, Indonesia \\ Email: mh_dira@yahoo.co.id \\ ${ }^{2}$ Prodi Ilmu Hukum, Universitas Madura, Pamekasan, Indonesia \\ Email: winyulli@unira.ac.id
}

\begin{abstract}
Abstrak
Penelitian ini mengkaji tentang pendidikan politik menyongsong pemilu Presiden dan Wakil PresidenRepublik Indonesia tahun 2019dalam fatsun demokrasi Pancasila dan Deliberatif. Hasilnya menunjukkan bahwa dalam fatsun demokrasi Pancasila dan deliberatif, dijumpai ajaran diskursus praktis, formasi opini publik dan aspirasi politik masyarakat, serta kedaulatan rakyat secara prosedural sebagai pemilik dan pemegang kedaulatan tertinggi yang diatur secara konstitusional di Indonesia serta dapat mengontrol keputusan-keputusanpemerintah yang dibentuk melalui pemilihan umum. Pendidikan politik merupakansarana untuk mengetahui hak dan kewajibannyaserta pertanggungan jawab warga negara Indonesia dalam kehidupan bernegara, selain itu tanggung jawab Presiden dan wakil Presiden Republik Indonesia terpilih dalam mengemban kekuasaan sebagai amanah. Tanggung jawab dalam pendidikan politik ini menjadi kewajiban partai politik, KPU-BAWASLU, dan seluruh elemen masyarakat dengan tujuan peningkatan pemahaman visi misi calon Presiden dan wakil Presiden Indonesia dalam diskursus publik sesuai dengan cita-cita dan tujuan negara Indonesia yang sampai saat ini belum tercapai.
\end{abstract}

Kata kunci: Politik, pilpres, fatsun, pancasila, deliberatif

\begin{abstract}
This paper a study political education to meet presidential elections and vice president of the republic of Indonesia of 2019 in fatsun democracy Pancasila and a deliberative.The results show that in fatsun democracy Pancasila and a deliberative, found the practical discursus, formation public opinion and political aspirations the community, and sovereignty the populace as procedural as the owner of and holder sovereignty highest dealt with in constitutional in Indonesia and can control government decisions that was formed through elections. Political education is a means of to understand rights and obligations and the responsibilities of a citizen in our nation and state, besides the responsibility of presidents and vice president of the republic of Indonesia was elected to carry power as the mandate. The responsibility of in education politics it is it is an obligation of a political party, KPU-Bawaslu, and all elements of the community with the aim of an increase in the understanding of the related the vision mission presidential candidates and a vice president been attained by Indonesia in discursus the public which had bought in accordance with idee and aim of the Indonesia state that is to date it has not yet been attained.
\end{abstract}

Keywords: Political education, presidential elections, fatsun, democracy pancasila, deliberative.

Subrhited: 31-01-2019; Accepted: 25-04-2019; Published: 30-04-2019

*Kotespondensi: Program Studi Ilmu Hukum, Universitas Madura Pamekasan

Jln. Raya Panglegur KM. 3,5 Pamekasan Madura Jawa Timur, Indonesia

Emall: mh_dira@yahoo.co.id 


\section{PENDAHULUAN}

Genderang pemilihan umum Presiden dan wakil Presiden Indonesia sudah mulai ditabu, hal ini ditandai melalui adanya pendaftaran calon Presiden dan wakil Presiden Indonesia. Konsep Pemilu tercipta dari gagasan Demokrasi yang berarti kebebasan, keadilan dan persamaan individu dalam segala bidang (Bachtiar Farahdiba 2014). Pada Pemilu Presiden dan wakil Presiden Indonesia tahun 2019 KPU telah menetapkan Pasangan calon Presiden dan wakil Presiden Indonesia Joko Widodo-Ma'ruf Amin dan Prabowo Subianto-Sandiaga Salahuddin Uno.

Pelaksanaan Pemilu Presiden dan wakil Presiden Indonesia melambangkan bentukaktualisasi demokrasi di Indonesia (Liando 2016).PemiluPresiden dan wakil Presiden Indonesia digelar tiap 5 tahun sekali yang mengindikasikan ciri Indonesia sebagai Negara hukum pancasila. Dalam pandangan Fukuyama negara hukum bertalian dengan demokrasi karena esensi negara hukum adalah kesediaan penguasa tunduk pada hukum.

Pelaksanaan pemilihan umum Presiden dan wakil Presiden Indonesia sangat esensial dan massif dalam Negara demokrasi modern versi Indonesia, karenanya selalu menimbulkan problematika sosio-kultural, meskipun selalu menimbulkan problem tetapi harus diadakan pemilihan umum Presiden dan wakil Presiden Indonesiakarena masa jabatan Presiden dan wakil Presiden Indonesia telah berakhir sesuai dengan pembatasan konstitusi, sehingga harus dilakukan pemilihan umum Presiden dan wakil Presiden Indonesia untuk mengisi jabatan ke-Presidenan di Indonesia. Oleh karena itu, teori negara hukum modern berbasis sistem pemerintahan Presidensiil mengajarkan harus ada Pemilu untuk menentukan Presiden dan wakil Presiden yang sengaja dipilih secara langsung oleh setiap individu, walaupun ada pengisian jabatan kepala negara berdasarkan keturunan seperti di Inggris, tetapi secara umum pemenuhan jabatan presiden dilaksanakan melalui Pemilu melalui sistem partai sebagai peserta Pemilu.

Dalam pemilihan umum secara langsung, maka rakyat dapat mengendalikan dan mengontrol keputusan pemerintahan yang terbentuk melalui pemilihan umum. Pelaksanaan Pemilu Presiden dan wakil Presiden Indonesia tahun 2019, akhirakhir ini kedua pasangan calon Presiden dan wakil Presiden sudah sangat 
menggeliat partai-partai politik serta tim sukses telah mulai menggelar pertemuan menarik perhatian publik.

Di lihat melalui kedaulatan rakyat, pemilihan umum Presiden dan wakil Presiden Indonesia adalah bentuk pelaksanaan kedaulatan rakyat yang benar dan menyenangkan.

Pemilu melalui sistem kepartaian ini rakyat akan memilih partai, kemudian partai-partai tersebut akan menjadi kandidat dalam pemilu yang akan mendeklarasikan nama-nama calonnya untuk menjabat sebagai anggota Parlemen.

Dalam kaitan ini, Pasal 172 Undang-Undang Nomor 7 Tahun 2017 mengenai Pemilihan Umum menegaskan (Undang-Undang Nomor 7 Tahun 2017.):

"Peserta Pemilu untuk pemilihan umum anggota DPR, DPRD provinsi, dan DPRD kabupaten/kota. adalatr partai politik"

Kemudian Pasal 173 Undang-Undang Nomor 7 Tahun 2017 tentang Pemilihan Umum menegaskan kembali bahwa:

"Partai Politik Peserta Pemilu merupakan partai politik yang telah ditetapkan/lulus verilikasi oleh KPU”.

Oleh karena itu, partai politik sebagai peserta pemilu dibebani kewajiban untuk melaksanakan pendidikan politik kepada konstituen yang dapat digelar melalui kampanye partai politik atau media lainnya.

Pendidikan politik bagi konstituen menyongsong Pemilu Presiden dan wakil Presiden Indonesia tahun 2019 dimaksudkan agar mampu mengahasilkan Presiden dan wakil Presiden Indonesia tahun 2019 yang jujur, amanah, kridibel, akuntabel dan berkualitas yang memiliki kekuasaan utama, sebagaimana ditegaskan di dalam Pasal 4 ayat (1) UUD RI Tahun 1945:

\section{"Presiden Republik Indonesia memegang kekuasaan Pemerintahan menurut Undang-Undang Dasar”.}

Jika memperhatikan pelaksanaan pemilihan umum Presiden dan wakil Presiden Indonesia Tahun 2004, 2009, dan tahun 2014 terdapat banyak kelemahan, di antaranya:

1. Sistem pemilu dan sistem perpolitikan di Indonesia belum stabil menemukan jati diri yang sepatutnya (Fauzi 2018), oleh sebab itu peraturan yang membahas Pemilihan Umum dan sistem partai politik selalu mengalami 
perubahan di mana setiap menjelang pelaksanaan pemilihan umum selalu membentuknorma hukum baru.

2. Gejolak bentur-membentur kepentingan pencalonan Presiden dan wakil Presiden Indonesia karena pencalonan Presiden dan wakil Presiden tidak dipilih menggunakanjalan konvensi.

3. Partai politik sebagai kontestan pada Pemilu dapat digolongkan berjumlah banyak, sehingga belum menyempitkan ruang gerak partai politik.

4. Terjadinya kesulitan masyarakat dalam menentukan pilihan untuk memilih dan menentukan calon yang diusung parpol.

5. Terjadinya kecurangan dalam segala segmen, sehingga menimbulkan sengketa pemilihan Presiden serta wakil Presiden saat itu.

6. Pelaksanaan pemilihan Presiden dan wakil Presiden belum membangunserta membentuk partisipasi masyarakat secara komprehensif.

7. Pemilihan umum tidak serentak sehingga terjadi in-efisiensi anggaran pemilu.

Pelaksanaan Pemilu Presiden dan wakil Presiden Indonesia tahun 2019 berbeda jika dibandingkan pada pelaksanaan sebelumnya, pada pelaksanaan tahun 2019 dukungan terhadap calon Presiden dan wakil Presiden ditentukan selepas pelaksanaan pemilu legislatif oleh partai politik. Karena Pelaksanaan pemilihan umum Presiden dan wakil Presiden Indonesia tahun 2019 dilaksanakan bebarengan dengan pemilu legislatif merupakan model pertama kali digelar di Indonesia dalam sejarah pemilu, sehingga Partai politik benar-benar eksis dan terus menggalang dukungan ke masyarakat dengan berbagai cara dilakukan untuk mengenalkan pasangan calon Presiden dan wakil Presiden yang didukung. Implementasi pemilihan umum secara bersamaan tidak terlepas pada keputusan Mahkamah Konstitusi Nomor 14/ PUU-11/2013 mengenai pemilihan umum yang diselenggrakan secara serentak (Solihah 2016). Bercermin dari keputusan tersebut, penyelenggaraan pemilihan umum 2019 ternyata belum mengatur pengoperasian yang mampu memperkuat system presidensial (Triono 2017).

Situasi demikian sangat menggeliat dan mereka seakan peduli terhadap kepentingan rakyat, karena mereka mencari popularitas semata dan mendapatkan dukungan serta hak suara dari rakyat. Namun demikian, ketika pelaksanaan pemilihan umum selesai, maka terkadang dianggap selesai urusan dengan rakyat 
dan ber-alih membangun kepentingan kelompok partai politik mereka. Hal inilah tentunya tidak boleh terjadi di negeri ini.

Ketika momen pelaksanaan pemilu berlangsung eksistensi partai politik sangat jelas menyuarakan kepentingan negara dan rakyat, tetapi ketika momen itu selesai, maka selesai pula tanggung jawab mereka. Seyogyanya fungsi partai politik melakukan pendidikan politik kepada konstituen luas tidak ada batasan waktu pelaksanaan pendidikan politik bagi konstituen baik sebelum pelaksanaan Pemilu ataupun setelah Pemilu sebagaimana pada masa menjaring dukungan dari rakyat.

Informasi dasar yang harus diketahui masyarakat di antaranya adalah:

1. Rekam jejak dari calon Presiden dan wakil Presiden (latar belakang pendidikan, kemampuan keilmuan).

2. Visi misi para calon Presiden dan wakil Presiden yang seharusnya merujuk kepada cita-cita dan tujuan nasional seperti halnya tertera pada pembukaan UUD RI Tahun 1945 sebagai bintang pemandu penyelenggarakan pemerintahan.

3. Bagi Petanahan seharusnya harus diketahui rekam jejak program kerja yang telah dilaksanakan dan hutang-hutang negara selama memimpin. Jika membangun negara dengan cara hutang ditengah melemahnya perekonomian negara, maka siapapun pemimpinnya pasti bisa.

\section{METODE PENELITIAN}

Penelitian ini menggunakan metode kualitatif melalui pendekatan kajian pustaka. Hal ini dilakukan untuk memudahkan mengungkap permasalahan pemilu yang perlu mendapatkan solusi dalam berbagai permasalahan politik dan pemilu di Indonesia.

Peneliti menggunakan teori rasionalitas untuk menganalisa permasalahan pendidikan politik pada pemilu deliberatif dengan mendasarkan pada demokrasi pancasila.

\section{HASIL DAN PEMBAHASAN}

Refleksi Perkembangan Pemilihan Umum Presiden dan Wakil Presiden diIndonesia 
Gagasan Pemilihan Presiden pada awalnya menjadi wacana yang memperoleh dukungan, akan tetapi masih ditemui penolakan dan keraguan. Pada dasarnya pelaksanaan Pemilihan umum Presiden secara langsung telah mendapat dukungan dengan salah satu alasan bahwa tolak ukur menjadi seorang calon presiden tidak dipunyai oleh masyarakat yang menyumbangkan suaranya. Namun, adakalanya ada yang kurang setuju, dengan alasan Rakyat dianggap belum memiliki kesanggupan untuk memilih Presiden secara langsung (Tamrin 2013).

Ketika reformasi tahun 1998 yang melahirkan banyak perubahan baik dari segi tatanan pemerintahan maupun tatanan partai politik hingga sistem pelaksanaan pemilu yang ditunjukkan melalui perubahan UUD 1945 pada tahun 1999 sampaitahun 2002. Pada tahun 1999 pemilu menghasilkan Presiden dan wakil Presiden Republik Indonesia, yaitu KH. Abdurrahman Wahid-Megawati di mana pada saat ini Presiden di pilih oleh MPR sehingga ia sebagai mandataris MPR, sebagai mandataris MPR Presiden dengan mudah dicabut mandatnya sebagaimana terjadi pada pemberhentiannya Abdurrahman Wahid di tengah jalan pemerintahannya, sehingga Megawati naik sebagai Presiden Indonesia hingga habis masa jabatan Presiden Abdurrahman Wahid tahun 2004.

Pelaksanaan Pemilu Presiden dan Wakil Presiden Republik Indonesia tahun 2004 untuk periode tahun 2009sangat berbeda dengan sebelumnya. Pemilu ini pertama kali diadakan di Indonesia dengan sistem pemilihan langsung oleh masyarakat. Pemilu ini dilaksanakan selama 2 putaran, yang dimenangkan oleh Presiden Susilo Bambang Yudhoyono dan Wakil Presiden Muhammad Jusuf Kalla.

Sedangkan pelaksanaan Pemilu Presiden dan Wakil Presiden Republik Indonesia Tahun 2009 untuk periode 2014, pasangan Susilo Bambang Yudhoyono dan wakil Presiden Boediono mampu menjadi pemenang dalam satu putaran langsung dengan mendapatkan suara sebanyak 60,80\%. Presentase tersebut telah mengunggulli pasangan Megawati Soekarnoputri-Prabowo Subianto dan Muhammad Jusuf Kalla-Wiranto.

Penentuan suara pasangan calon terpilih pada pemilu Presiden tahun 2009 yakni pasangan calon yang mendapatkan suara lebih dari 50\% dari jumlah suara dengan sedikitnya $20 \%$ suara pada setiap provinsi yang tersebar lebih dari $50 \%$ jumlah provinsi di Indonesia. 
Perbedaan ditemukan pada pelaksanaan Pemilihan umum Presiden tahun 2014 sampai dengan periode tahun 2019. Pada saat pemilu Presiden tahun 2014 Presiden Susilo Bambang Yudhoyono tidak diperbolehkanmencalonkan dirikembali dalam Pemilu Presiden sebab sebelumnya telah menjadi presiden pada periode 2005 dan periode 2014 . Dalam UUD RI Tahun 1945 terdapat peraturan mengenai batas masa menjabat sebagai Presiden yang diatur di pada Pasal 7 UUD RI Tahun 1945, berbunyi:

"Presiden dan Wakil Presiden memegang jabatan selama lima tahun dan sesudahnya dapat dipilih kembali dalam jabatan yang sama, hanya untuk satu kali masa jabatan”.

Pada saat itu Susilo Bambang Yudhoyono tidak maju kembali dalam pemilihan umum Presiden, maka pemilihan umum ini terdapat dua pasang calon yang mencalonkan diri sebagai Presiden dan Wakil Presiden yakni,Prabowo Subianto-Hatta Rajasa dan Joko Widodo Gubernur DKI Jakarta berpasangan dengan Jusuf Kalla, dan KPU memutuskan Joko Widodo-Jusuf Kalla sebagai Presiden Indonesia yang dilantik tanggal 20 Oktober 2014 setelah melalui proses sengketa Pilpres tahun 2014.

\section{Membangun Pendidikan Politik Menuju Pemberdayaan Masyarakat}

Istilah political sosialization memiliki arti sosialisasi politik. Karenanya istilah political sosialization disamakan dengan pengertian pendidikan politik dengan istilah sosialisasi politik. Sebenarnya sosialisasi politik tidak dapat disamakan dengan pendidikan politik karena dalam sosialisasi politik bisa bermakna penyampaian keinginan politik para calon Presiden dan wakil Presiden yang menjurus kearah mobilisasi masyarakat ke dalam satu calon Presiden dan wakil Presiden tertentu yang dapat bermakna positif atau negatif.

Pendidikan politik dimaknai suatu tindakan memberi ajaran, latihan, maupun pengarahan untuk menumbuhkan kemampuan masyarakat serta calon Presiden dan wakil Presiden, dengan proses dialogis yang dilaksanakan oleh partai politik dan pemerintah sebagai pihak yang bertanggung jawab pemajuan bangsa. Atau dapat dikatakan pendidikan adalah sarana atau wadah meningkatkan pengetahuan hak dan kewajiban warga negara termasuk politik bagi rakyat agar dapat berpartisipasi secara maksimal dalam menggunakan hak politik mereka dalam pemilihan di Indonesia(Hamidi 2008). 
Nadira: MEMBANGUN PENDIDIKAN POLITIK

DALAM FATSUN DEMOKRASI PANCASILA

DAN DELIBERATIVE

Dalam kaitan ini Sudarwo menilai pendidikan politik pemberdayaan masyarakat, merupakan suatu proses peningkatan kapasitas masyarakat dalam meningkatkan kwalitas kehidupa (Sudarwo 2016). Oleh karena itu, prosedur dan media pendidikan politik dalam perspektif pemberdayaan memiliki 2 output. Pertama, output strategis ideologis. Kedua, output praktis pragmatis basic need. Dengan demikian, ada 5 model pendidikan politik berbasis pemberdayaan masyarakat yakni:

1. Menggerakkan serta meningkatkan kemampuan warga dalam memenuhi kebutuhan dasar mereka.

2. Analisis kesadaran kritis pada lingkungan sosial, ekonomi, politik serta ekosistem lingkungan warga.

3. Meningkatkan pembangunan akses ke dalam berbagai pos-pos sumberdaya yang mampu mendukung kehidupan warga.

4. Meningkatkan partisipasi organisasi warga sehingga dapat berasosiasi dan kerjasama antar partai poltik.

5. Meningkatkan dan menciptakan kontrol sosial dalam kebijakan publik.

Kurangnya pendidikan politik masyarakat Indonesia menyebabkan masyarakat tidak memahami visi misi calon Presiden dan wakil Presidenbahkan kurang mengerti hak serta kewajibannya dalam pelaksanaan pmilihan umum Presiden dan wakil Presiden sehingga mudah dimobilisasi untuk kepentingan calon-calon tertentu tanpa mengetahui track recordnya. Dalam demokrasi modern proses demokrasi yang baik dan sehat menentukan syarat terjadinya partisipasi politik yang merespon semua kepentingan masyarakat atau rakyat melalui komunikasi ruang publik.Untuk membangun partisipasi politik yang responsif, maka diperlukan pendidikan politik masyarakat warga yang memadahi dan kemapanan lembaga partai politik.

\section{Model Pendidikan Politik Dalam Fatsun Demokrasi Pancasila}

Lembaga-lembaga politik menyusun seperangkat kaidah mengenai demokrasi yang akan dilaksanakan. Hal ini kerap dianggap bahwa lembaga politik mudah disalahgunakan, untuk orientasi baik maupun buruk dalam sistem Pemilihan Umum.

Pendidikan Politik merupakan suatu rangkaian pembelajaran kesadaran 
tentang hak, kewajiban, serta tanggung jawab rakyat dalam menjalankan kehidupan berbangsa dan bernegara serta tanggung jawab sebagai Presiden dan wakil Presiden Republik Indonesia dalam mengemban kekuasaan sebagai amanah. Dalam mengemban kekuasaan sebagai amanah, maka calon Presiden dan wakil Presiden tidak melupakan visi misi yang sesuai pada cita cita nasional Indonesia, bahkan visi misi dalam kampanye itu menjadi pacta sunservanda antara calon Presiden dan wakil Presiden yang terpilih dengan warga negara sebagai pemilih, pemilik kedaulatan tertinggi dalam demokrasi modern.

Dalam demokrasi Pancasila, pendidikan politik harus berintikan:

1. Nilai Ketuhanan Yang Maha Esa, tidak boleh ajaran-ajaran lain masuk dan disebarkan melalui sarana pendidikan politik.

2. Penghormatan, pengakuan dan pemartabatan hak asasi manusiaselaku pemilih dalam pemilihan Presiden dan wakil Presiden

3. Persamaan dan kelayakan bagi setiap pemilih baik dari golongan partai pengusung Presiden maupun bukan.

4. Mencirikan semangat keadilan sosial bagi seluruh rakyat Indonesia sebagai nilai hakiki.

5. Mengagungkan moral dan budi pekerti yang luhur dalam kehidupan berbangsa serta bernegara.

6. Menegakkan partsipasi serta transparansi pada setiap proses pengambilan kebijakan bagi pemerintah sebagai ciri khas negara hukum Pancasila (asas musyawarah-mufakat).

Undang-Undang Nomor 2 tahun 2011 mengenai Perubahan atas UndangUndang Nomor 2 Tahun 2008 Mengenai Partai Politik belum menyebutkan seperti apa serta bagaimana bentuk pendidikan politik yang harus dilakukan, tetapi cukup menegaskan, yaitu:

1. Bantuan keuangan dari Anggaran Pendapatan dan Belanja Negara/Anggaran Pendapatan sertaBelanja Daerah diutamakan untuk menyelenggarakanpendidikan politik bagi peserta Partai Politik dan rakyat.

2. Pendidikan Politik erat kaitannya dengan tindakan:

a. Pengkajian tentang empat pilar berbangsa serta bernegara yakni Pancasila, UUD 1945,Bhinneka Tunggal Ika serta Negara Kesatuan Republik Indonesia; 
b. Penafsiran tentang hak dan kewajiban warga negara Indonesia dalam rangka menciptakan etikaserta budaya politik; dan

c. Kaderisasi anggota Partai Politik secara bertingkat dan berkelanjutan.

Seiring dengan ketentuan tersebut dalam perspektif menyongsong Pemilihan Presiden dan wakil Presiden Indonesia tahun 2019 setidak-tidaknya dapat direkonstruksikancita pendidikan politik bagi masyarakat sebagai konstituen sebagai berikut:

1. Peningkatan pemahaman visi misi calon Presiden dan wakil Presiden Indonesia dalam diskursus publik kepada semua elemen masyarakat guna diketahui capaian akhir visi misinya sesuai dengan cita-cita dan tujuan negara Indonesia yang sampai saat ini belum tercapai.

2. Peningkatan daya pengetahuan masyarakat mengenai track recordcalon Presiden dan wakil Presiden Indonesia tentang: latar belakang pendidikan, kompetensi pedagogi, kompetensi personal, kompetensi sociocultural, kompetensi pengetahuan ilmu hukum dan ilmu-ilmu lainnya, kompetensi moral, kemampuan mengelola negara.

3. Peningkatan pengetahuan dan pemahaman masyarakat mengenaitrack record hutang negara selama menjadi Presiden dan wakil Presiden Indonesia. Uraian tersebut berhubungan dengan kesejahteraan masyarakat. Semakin besar hutang negara, semakin kecil membangun kesejahteraan.

4. Peningkatan partisipasi masyarakat dan transparansi dalam proses pengambilan kebijakan.

5. Moral dan budi pekerti yang luhur bagi calon Presiden dan wakil Presiden

6. Peningkatan pengetahuan masyarakat tentang janji-janji kampanye yang tidak terealisasikan dengan baik.

7. Peningkatan pengetahuan dan pemahaman etika politik dan budayanya di Indonesia.

8. Peningkatan pengetahuan dan pemahaman mengenai hak memilih dan hak dipilih serta kewajiban masyarakat dalam kehidupan berbangsa dan bernegara.

9. Bertambahnya pemahaman mekanisme pemilihan.

Dalam Instruksi Presiden Nomor 12 tahun 1982 mengenai Pola Pembinaan serta Pengembangan Pendidikan Politik Golongan muda disebutkan bahwa Pendidikan politik adalah serangkaian upaya mengembangkan serta mengukuhkan 
kesadaran politik serta kenegaraan untuk mendukung kelestarian Pancasila dan UUD 1945 sebagai budaya politik bangsa.

Nilai-nilai tersebut di atas merupakan nilai-nilai Pancasila sebagai abstraksi dari realitas sosial masyarakat Indonesia sebelum membentuk negara yang merupakan hasil perenungan jiwa yang mendalam yang dilaksanakan oleh the faounding people Indonesia yang ditertera dalam satu kesatuan sistem filsafat Pancasila, yaitu nilai-nilai Pancasila saling mengisi dan saling menguatkan antara sila yang satu dengan sila Pancasila lainnya.

Kemudian asas-asas pelaksanaan pendidikan politik bagi generasi muda seperti tercantum dalam Inpres Nomor 12 Tahun 1982, meliputi asas umum, keterpaduan. demokrasi, manfaat, bertahap, berjenjang, dan berkelanjutan, aman.

Dalam hubungan ini Gaffar menilai, sedikitnya ada 3 penyebab utama terkait alasan pendidikan politik serta sosialisasi politik di Indonesia belum mampu menyumbangkan kesempatan untuk menaikkan partisipasi politik masyarakat, yaitu:

1. Dalam masyarakat Indonesia anak-anak tidak dibimbing menjadi individu yang mandiri. Anak-anak justru menghadapi keterasingan didalam politik keluarga. Beberapa keputusan krusial dalam keluarga, seperti halnya keputusan mengenai nasib anak, adalah ranah orang yang lebih tua. Dalam hal tersebut, anak-anak tidak diikutsertakan.

2. Jenjang politisasi sebagian terbesar masyarakat di Indonesia sangat rendah. Pada golongan keluarga miskin, buruh, petani dan lain sebagainya, belum mempunyai kesadaran politik yang cukup, sebab mereka lebih bertumpu kepada kehidupan ekonomi dibandingkan dengan merenungkan segala hal yang berbau politik. Menurut mereka, keterlibatan pada wacana politik mengenai hak-hak serta kewajiban setiap masyarakat, hak asasi manusia dan sejenisnya, dipungkiri bukan ukuran utama yang teramat penting.

Dalam kaitan ini, Miriam Budiardjo mengemukakan bahwa partai politik mempunyai sejumlah fungsi yang dapat difungsikan untuk melaksanakan pendidikan politik di antara beberapa fungsi yang lain, di mana dalam negara modern, partai politik memiliki fungsi:

1. Sebagai Sarana Komunikasi Politik 
Parpol berfungsi mennyampaikan beragam argumentasi masyarakat dan mengaturnya sedemikian rupa agar ketidakjelasan opini masyarakat dapat berkurang.

2. Sebagai Sarana Sosialisasi dan Pendidikan Politik

Pada ilmu politik, sosialisasi politik merupakan proses setiap individu mendapatkan sikap dan tujuan terhadap suatu gejala politik dalam wilayah tempat keberadaannya. Sosialisasi politik dalam implementasinya biasanya dilaksanakan melalui kajian pidato penerangan, kursus penataran, kursuskursus kader, dan sebagainya.

Seiring dengan fungsi partai politik di atas, maka partai politik dibebani tanggung jawab sebagai salah satu kewajiban memberikan pendidikan politik kepada masyarakat berupa arahan kepada masyarakat bagaimana menjadi warga negara yang beradab, demokratis, jujur, serta amanah dalam kehidupan berbangsa dan bernegara bahkan KPU sebagai penyelenggara Pemilu atas nama negara berkewajiban mendidik masyarakat agar menjadi warga yang demokratis, beradab menyongsong Pemilu Presiden dan wakil Presiden Indonesia Tahun 2019 dikarenakan perkembangan masyarakat Indonesia menuntut peningkatan peran, fungsi, serta tanggung jawab partai politik dalam kehidupan demokrasi konstitusional yang berbasis Pancasila sebagai media partisipasi politik masyarakat bangsa Indonesia.

\section{Model Pendidikan Politik Dalam Fatsun Demokrasi Deliberative}

Jika memperhatikan gagasan demokrasi deliberativeyang cetuskan oleh Jurgen Habermas tentunya tidak lepas dari faktor socio-kultural saat itu, di mana melihat keringnya partisipasi masyarakat di dunia barat yang tidak memiliki ruang konsultasi publik dalam ranah politik, ekonomi, dan hukum pada dasarnya bukan hal baru bagi demokrasi Pancasila. Karena demokrasi deliberatif menitikberatkan urgennya mekanisme komunikasi dalam memperoleh legitimasi hukum di dalam suatu proces pertukaran yang dinamis antara sistem politik dengan ruang publik yang dimobilisasi secara kultural (Budi Hardiman 2009a).

Secara harfiah istilah deliberative berasal dari kata "deliberation". Istilah tersebut memiliki arti konsultasi, musyawarah. Teori demokrasi deliberative tidak menitikberatkan pada seperangkat aturan, melainkan pada proses dalam 
melahirkan aturan-aturan itu. Di sisi lain, teori demokrasi deliberative ini meletakkan bagaimana keputusan politik itu diambil dalam keadaan manakah aturan itu bisa dihasilkan, sehingga warga negara mematuhi aturan itu(Budi Hardiman 2009b).

Demokrasi deliberative mempunyai makna tersirat didalamnya, yakni diskursus praktis, formasi opini publik dan aspirasi politik, dan kedaulatan rakyat sebagai prosedur. Opini publik mampu menjadi pendapat mayoritas yang mengaku legitimasi mereka (Budi Hardiman 2009c). Oleh karena itu, demokrasi deliberative bertumpu pada formasi pendapat dan aspirasi secara demokratis itu sendiri. Dengan demikian, demokrasi deliberatif ingin membuka ruang yang besar atas partisipasi warga Negara, dan keputusan politis harus diuji secara publik, sehingga dalih itu diterima secara intersubjektif oleh semu warga negara dan tidak menutup diri kritik-kritik masyarakat. Hal ini merupakan suatu usaha untuk semakin mendekat pada cita cita demokrasi itu sendiri.

Bagi Habermas ruang publik suatu jaringan yang mengkomunikasikan informasi dari berbagai cara pandang yang disaring sedemikian rupa, sehingga menjadi opini publik yang relevan dengan permasalahan masyarakat. Ruang publik merupakan fenomena sosial seperti tindakan, pelaku, atau kolektivitas, tetapi ruang publik melampaui konsep sosiologi konvensional tentang tatanan sosial (Wattimena 2007).

Cita pendidikan politik yang ingin dibangun dalam konsep demokrasi deliberatif paling tidak, yaitu:

1. Diskursus publik antara calon Presiden dan wakil Presiden dengan masyarakat sebagai konstituen dalam menyampaikan visi, visi yang akuntabel.

2. Partisipasi masyarakat sebagai konstituen dalam menyampaikan aspirasi kepada calon Presiden dan wakil Presiden guna menghasilkan kebijakan yang responsif.

3. Kedaulatan rakyat sebagai konsekuensi fasilitasi diadakannya pelaksanaan pemilihan umum, karena rakyat sebagai pemilik dan pemegang kedaulatan tertinggi.

4. Harmonisasi antara pemerintah dengan yang diperintah (pemerintah dengan warga negara).

5. Uji publik kebijakan pemerintah sebelum dilaksanakan, khususnya dalam bidang ekonomi dan Sumber Daya Alam. 
Nadira: MEMBANGUN PENDIDIKAN POLITIK

DALAM FATSUN DEMOKRASI PANCASILA

DAN DELIBERATIVE

Dalam demokrasi deliberative, rakyat sebagai pemilik kedaulatan dapat mengontrol keputusan-keputusan publik. Apabila rakyat sudah nekat mengkritik kebijakan pemerintah, maka mereka sudah dikategorikan menjadi rakyat rasional. Pendapat publik mampu mengontrol politik formal maupun kebijakan-kebijakan politik. Bilamana rakyat cenderung patuh, maka mereka dinilai tidak mempunyai keberanian dalam mengkritik bagaimana kebijakan politik yang sedang diterapkan.

Dalam kaitan ini Fatkhurohman berpendapat, bahwa dalam demokrasi deliberativenegara rakyat sudah mampu berpengaruh dalam pembentukan norma hokum dan kebijakan politik. Area publik menjadi arena di mana peraturan perundang-undangan sebagai norma hukum tertulis dipersiapkan dan diarahkan secara diskursive.

Seiring dengan diskursus demokrasi, maka Kranenburg mengemukakan, paling tidak dijumpai tiga ciri demokrasi modern, yaitu:

1. Representative popular government with a parliamentary system.

2. Representative popular government with separation of power.

3. Representative popular government subyect to some direct popular influence (e.g. referendum, or popular initiative).

Dalam kaitan ini Carlyle mengemukakan bahwa aspek pertama dan utama yang mendasar dari pemikiran politik pada abad pertengahan adalah otoritas politik merupakan ekspresi dari keadilan sebuah prinsip yang diperoleh langsung dari hukum Romawi, prinsip penting yang kedua adalah hanya terdapat satu sumber otoritas politik, yaitu masyarakat itu sendiri. Dalam hubungan ini John Salisbury seorang filsuf Inggris di mana ia seorang pejuang ambisius demi kebebasan individual mengemukakan bahwa setiap penguasa mempunyai tanggung jawab terhadap masyarakatnya (M. Ketchum 2004).

\section{KESIMPULAN}

Pendidikan Politik merupakan sarana untuk memahami hak dan kewajiban serta tanggung jawab warga negara dalam kehidupan berbangsa dan bernegara, disamping itu tanggung jawab Presiden dan wakil Presiden Republik Indonesia terpilih dalam mengemban kekuasaan sebagai amanah. Tanggung jawab dalam pendidikan politik ini menjadi kewajiban partai politik, KPU-BAWASLU, dan 
seluruh elemen masyarakat. Bentuknya seperti pengarahan kepada masyarakat pada waktu kampanye dan penyebaran informasi pemilu guna menjadi warga negara yang beradap, demokratis, adil dan humanis. Adapun cita dari pendidikan politik ini adalah: (1) Peningkatan pemahaman visi misi calon Presiden dan wakil Presiden Indonesia dalam diskursus publik kepada semua elemen masyarakat guna diketahui capaian akhir visi misinya sesuai dengan cita-cita dan tujuan negara Indonesia yang sampai saat ini belum tercapai. (2) Peningkatan daya pengetahuan masyarakat mengenai track recordcalon Presiden dan wakil Presiden Indonesia tentang: latar belakang pendidikan, kompetensi pedagogi, kompetensi personal, kompetensi sociocultural, kompetensi pengetahuan ilmu hukum dan ilmu-ilmu lainnya, kompetensi moral, kemampuan mengelola negara. (3)Peningkatan pengetahuan dan pemahaman masyarakat mengenaitrack record hutang negara selama menjadi Presiden dan wakil Presiden Indonesia. Hal ini erat kaitannya dengan kesejahteraan rakyat, semakin besar hutang negara, semakin kecil membangun kesejahteraan. (4) Peningkatan partisipasi masyarakat dan transparansi dalam proses pengambilan kebijakan.(5) Moral dan budi pekerti yang luhur bagi calon Presiden dan wakil Presiden. (6) Peningkatan pengetahuan masyarakat tentang janji-janji kampanye yang tidak terealisasikan dengan baik. (7) Peningkatan pemahaman mekanisme pemilihan. Dalam fatsun demokrasi Pancasila dan deliberative, dijumpai kesamaan di mana sama-sama mengajarkan diskursus publik, partisipasi politik masyarakat, serta kedaulatan rakyat sebagai pemegang kedaulatan tertinggi yang diatur secara konstitusional di Indonesia dapat mengontrol keputusan-keputusan melalui kedaulatan rakyat.

\section{REFERENSI}

Undang-Undang Nomor 7 Tahun 2017 Mengenai Pemilihan Umum.

Bachtiar Farahdiba, R. 2014. "Pemilu Indonesia : Kiblat Negara Demokrasi Dari Berbagai Refresentasi.” Jurnal Politik Profetik 3(1).

Budi Hardiman, F. 2009a. Demokrasi Deliberatif. Yogyakarta: Kanisius Press.

Budi Hardiman, F. 2009b. Demokrasi Deliberatif.

Budi Hardiman, F. 2009c. Demokrasi Deliberatif.

Fauzi, Agus Machfud. 2018. "Pengembangan Integrasi Sidalih Antara Pilwali Surabaya Dan Pilgub Jawa Timur: Optimalisasi Pelayanan Publik Kpu Kota Surabaya." JPSI (Journal of Public Sector Innovations). 3(1): 1-5. 
Hamidi, Jazim. 2008. Pembentukan Perda Partisipatif. Jakarta: Prestasi Pustaka.

Liando M Daud. 2016. "Pemilu Dan Partisipasi Politik Masyarakat." Jurnal LPPM Bidang EkoSosBudKum 3(2).

M. Ketchum, Richard (ed). 2004. Pengantar Demokrasi. Yogyakarta: Niagara.

Solihah, Ratnia. 2016. "Peluang Dan Tantangan Pemilu Serentak 2019 Dalam Perspektif Politik." Jurnal Ilmiah Ilmu Pemerintahan 3(1).

Sudarwo, Fajar. 2016. "Pemberdayaan Masyarakat Sebagai Penekatan Pendidikan Politik Untuk Mencegah Konflik Pemilukada.” 2018.

Tamrin, Abu. 2013. "Urgensi Pemilu Presiden Dan Wakil Presiden Secara Langsung Di Era Reformasi.” Jurnal Cita Hukum 1(2):189.

Triono. 2017. “Menakar Efektivitas Pemilu Serentak 2019.” Jurnal Wacana Politik 2(2).

Wattimena, Reza A. A. 2007. Melampaui Negara Hukum Klasik. Yogyakarta: Kanisius Press. 